\title{
MARKETINGORIENTÁLT VÁROSFEJLESZTÉS
}

\author{
(Marketing Oriented City Development)
}

\author{
HEGYI FATIME BARBARA
}

Kulcsszavak:

városfejlesztés marketingorientáció versenyképesség stratégia elemzés fejlesztés kommunikáció A tanulmány bemutatja mindazon tényezóket, amelyek hatékonnyá és eredményessé teszik a marketingorientált városfejlesztést. Mindehhez kidolgozza a marketingorientált városfejlesztés elméleti modelljét (MOVE), melynek helyes alkalmazása keretet biztosit a város vezetése számára a település versenyképességének kialakitásához és növeléséhez a város piacon történó megjelenitésén keresztül. A modell segitségével látható, hogyan kerül piacra a város, milyen vezetési szemlélettel és gyakorlattal valósitható meg egy olyan típusú településfejlesztési gyakorlat, amely a piaci igényeket sikeresen képes követni és szolgálni. Egy olyan alkalmazható elméleti modell kialakitása a cél a településfejlesztés területén, amelynek helyes alkalmazása hozzájárul a település versenyképességének kialakitásához és fenntartásához.

\section{Elöszó}

A tanulmány erősíteni kívánja a marketing tudományának azon szemléletét, amely nem a kommunikációs és PR tevékenységeket helyezi elötérbe, hanem a fogyasztói igényeket követve alakítja ki termékét a város iránti preferencia megteremtése érdekében. Mindehhez elengedhetetlen a fogyasztói igényekre épülö településfejlesztési stratégiaalkotás, valamint a stratégiát megvalósitó intézményi és személyi háttér biztositása és a fejlesztések kommunikálása a fogyasztók irányába, amelyek a MOVE modell fó elemei.

\section{A településfejlesztés fogyasztói igényeket követö gyakorlata: az alap- probléma}

Az 1980-as évekig a városok közötti verseny nem volt jelen Magyarországon, hiszen a települések fejlödése központi döntésektől függött, és így a versenyképesség alapját nyújtó helyi adottságok, erőforrások, helyi társadalom, illetve a kedvező társadalmi, természeti, kulturális környezet szinte alig játszott szerepet a fejlődésben, a fejlesztésben (Koltai 2004). A verseny a rendszerváltás után kezdett el kialakulni az önkormányzati törvény létrejöttével, melynek során módosultak a városfejlödés lehetöségei, kialakultak a városok önrendelkezésének keretei, és így a települések adottságai váltak versenyképességük motorjává.

Az önkormányzati törvény megszületésével - vagyis az önkormányzati rendszer kialakulásával - a magyarországi települések jelentős autonómiára tettek szert, amely nagyobb teret biztosított önszerveződö tevékenységeik, illetve fejlesztési elképzeléseik számára. A decentralizációs folyamat révén a városok kezébe került a 
lehetőség, hogy forrásokért, funkciókért, befektetésekért versengjenek, hozzájárulva így a település sikeréhez, azaz a település versenyképességének kialakításához és fenntartásához. Mindez a változás természetszerủleg nagy kihívást jelent az önkormányzati tevékenységek, szemléletmódok, fejlesztések és a vezetés számára. A fejlődés és fejlesztés kereteit több törvény is moderálja, amelyek lehetőséget teremtenek az önkormányzat számára ahhoz, hogy az önkormányzat a település erősségeire, lehetőségeire építse fel fejlesztési stratégiảját, és ez által alakítsa ki a település versenyképességét.

Mivel az önkormányzatok önigazgatási jelleggel mủködnek, saját eszközeikkel kell elérniük a város céljait, és megoldaniuk a város problémáit. Az önkormányzati törvény igen nagy szabadságot biztosít az önkormányzatok számára olyan tekintetben, hogy lehetőségeiken belül ellássák mindazon feladatokat, amelyeket szükségesnek éreznek, illetve amelyek nem tartoznak más szerv hatáskörébe. Így, a városi vezetés önállóságának növekedésével együtt jár a funkciók, a feladatok számának a növekedése is, ami hajtóeröt jelent afelé, hogy az önkormányzatok a piac nyújtotta lehetöségek felé nyissanak. A települések fejlesztése során mindez megköveteli az önkormányzatok részéről, hogy az önkormányzati döntések, illetve fejlesztések a piaci igényeket szolgálják.

Ezért a marketingorientált városfejlesztés egy piacorientált szemléletü várostervezést igényel és feltételez, amelyben több funkció is a piac elvárásainak megfelelően mủködik. Ma a településekhez kapcsolódó funkciók egy valós vagy látens piac keretei között müködnek. A stratégiai várostervezés során a piaci vonásoknak kell megerősödniük, azaz a figyelem középpontjában a kereslet igényeihez való igazodásnak kell állnia. A felülról irányított településfejlesztési folyamatot egy olyan gyakorlatnak kell felváltania, amely megjeleníti a valós és potenciális fogyasztók igényeit a várostervezésben.

Mindez nehéz feladatok elé állítja az önkormányzatokat, hiszen ma a települések között hasonlóan nagy a verseny, mint az üzleti szférában. Ahogyan az üzleti világban is, egy település csakis úgy képes fennmaradni és fejlödni, hogyha létezö felhasználói igényeknek tud hatékonyan megfelelni, ezért is szükséges a város piacorientált müködtetése. Következésképp az önkormányzatoknak a versenyszférában alkalmazott vezetési és fejlesztési szemlélet elsajátításával és alkalmazásával kell kialakítaniuk terméküket; magát a várost.

Mindezeket összefoglalva, a törvényi keretek által megteremtett lehetőségekkel élve, az önkormányzat egy olyan rendszerként értelmezhető, amelyben a rendszer termékeinek a fogyasztói az adott területen élő vagy ott valamilyen tevékenységet végző állampolgárok, illetve az ott müködő gazdasági társaságok és egyéb intézmények (1.ábra). A rendszerben a választópolgárok által megválasztott személyek, illetve az általuk választott professzionális apparátus végzi az önkormányzati tevékenységeket. A rendszerben az erőforrásoknak a fogyasztói igényeken keresztül történő, a fogyasztói tevékenységeknek keretet adó feltételrendszerré formálása jelöli azt az átalakítási folyamatot, amelyet a rendszert körülvevő szemléleti közeg elvárásai, elképzelései, nézetei alakitanak. A rendszer tulajdonosa a törvényhozói 
testület, illetve a választópolgárok közössége, amelyre jelentős hatást gyakorol a külső környezet, vagyis a magyarországi, illetve helyi társadalmi, politikai, szociológiai, kulturális, jogi és gazdasági környezet (Bányai 1993).

\author{
1. ÁBRA \\ A marketingszemléletü önkormányzati tevékenység \\ (Local Governmental Activity from Marketing Perspective)
}

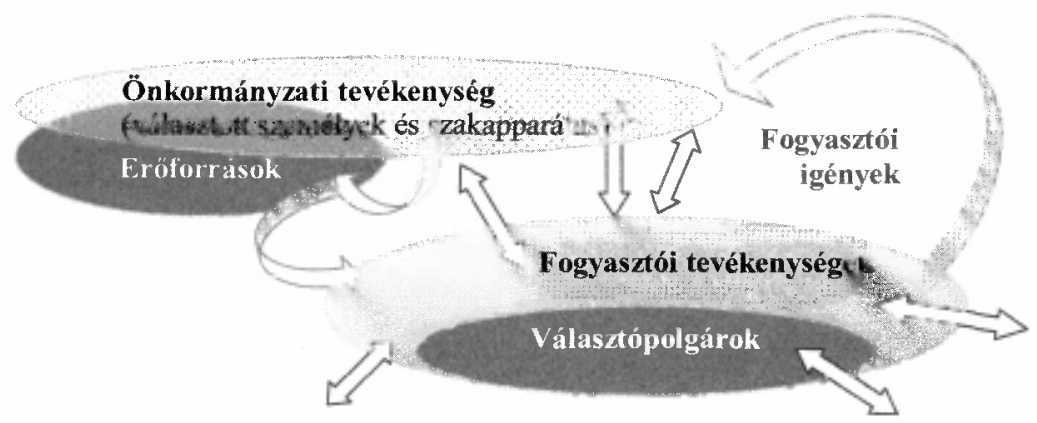

Forrás: Saját szerkesztés.

\title{
A város mint termék
}

A város egy különleges árucikk, amelyet a települések piacán kell eladni, így a várost át kell formálni egy piacképes településsé. Az eladandó termék maga a település, amely egy komplex szolgáltatáscsomagként értelmezendő; a település által kínált szolgáltatások, beruházási lehetőségek, a településen felhasználható kedvezmények, a környék, a turisztikai értékek összességét jelenti. A terméket a vevőhöz az önkormányzat fejlesztési tevékenységeivel, illetve kommunikációs képességével képes eljuttatni.

Ahhoz, hogy a város mint termék funkcionálhasson, az önkormányzatok esetében a piaci megfontolások mellett sok egyéb szemléletnek kell megvalósulnia. Elsőként a terméknek szükségletorientáltnak kell lennie, azaz a település funkcióinak, tevékenységeinek tükröznie kell a fogyasztók valós igényeit, szükségleteit. A településnek, mint terméknek társadalompolitikai felelössége is van, illetve felelössége hosszú távú, így az önkormányzatnak minden döntésében szem elött kell tartania, illetve érvényesítenie kell a hosszú távú közösségi érdekeket és értékrendet. Továbbá, a településnek környezettudatos magatartást kell tanúsítania, illetve jövö- és akcióorientáltnak kell lennie, tehát a fenntartható fejlödés mellett az elöremutató, ösztönzö, pro-aktív megoldások és kezdeményezések mellett kell elköteleznie magát. Mindezek mellett a polgárokhoz közeli magatartást kell mutatnia, amely során az információk elérhetősége és a részvétel mellett fontos a fogyasztói elégedettség mérése is. Az autonóm és vállalkozói szellemiségnek is aktívan jelen kell lennie a különféle együuttmúködések és célok megvalósítása során, valamint egy határozott innovációs 
törekvést kell biztosítania, hozzájárulva ezáltal a dinamikus fejlődéshez, a kreatív ötletek sikerességéhez. Legvégül egy politikailag kiegyensúlyozott légkört kell teremtenie, amely bizalmat sugároz a fogyasztók felé, ekképp növeli a fogyasztói és befektetöi kedvet a településen (Piskóti et al 2002).

Összességében egy rendkívül rugalmatlan és komplex termék a város, amit csak hosszú idő alatt és jelentös anyagi ráfordítással lehet a fogyasztók igényeihez alakítani, hiszen már a piacok kiválasztásában is igen korlátozott az önkormányzat szabadsága, mert vannak csoportok, akikkel minden esetben foglalkoznia kell a fejlesztéseknek - a megtérüléstől és hatásoktól függetlenül. A termék komplexitását jelzi továbbá, hogy célcsoportjai rendkivül heterogének, így sok esetben létező és valós érdekkonfrontációk adódnak. A fogyasztási cikkektől leginkább abban tér el ez a termék, hogy az épített környezet és a szolgáltatások bizonyos csoportjait kell eladni a célszegmenseknek, nem a település egészét. Érzékelhetö, hogy a termék nem megfogható és nem is raktározható, csupán a termékkel kapcsolatos kommunikáció és információ. A termék eladása során a tulajdonjog nem cserél gazdát, valamint a tulajdonformák sokfélesége is tovább növeli a termék összetettségét. További különlegessége a település-terméknek, hogy ugyanazt a fizikai teret egyidejüleg másmás, eltérő igényekkel rendelkező fogyasztóknak is el kell tudni adni, így amellett, hogy a termék helyhez kötött, mégis térbeli eltéréseket mutat a kereslet-kínálat. A termékre jelentős hatása van a politikai megfontolásoknak, valamint jelentős a régióból, országból ható árnyékhatás, hiszen a település nem tudja kiszakítani magát az adott területről, környezetböl, ahogyan ezt az 1. ábra is szemlélteti.

Ma a városok versenyében minden város részt vesz, de ennek a részvételnek az alapját nem is a városok egésze adja, hanem a városban fellelhetỏ különféle érdekcsoportok (Horváth 2001). Ennek oka a város, mint termék vagy mint szolgáltatáscsomag komplexitásában rejlik, hiszen a városok esetében nem elegendó a gazdasági hatékonyság megteremtése és fenntartása, hanem mindezt kulturálisan, társadalmilag, politikailag is meg kell tudnia teremteni az önkormányzatnak. İgy csakis akkor adható el a termék a fogyasztók kiválasztott csoportjainak, ha a település fejlesztései összhangban vannak a fogyasztók igényeivel, amit tovább nehezit, hogy bonyolult pontosan mérhető célokat kitüzni, illetve csak hosszú távon teljesedik ki a marketingorientált településfejlesztési tevékenységek hatása.

Ezért a marketingorientált településfejlesztés magába foglalhatja a település bármely jellemzöjét, adottságát vagy lehetöségét, amivel fel tudja kelteni a piac, vagyis a fogyasztók érdeklódését, illetve amely által ki lehet elégíteni egy igényt. Mindez lehet egy szervezet, egy szolgáltatás, egy fejlesztési program, egy eszme, egy világkép, de akár a biztonság vagy a tisztaság is.

Így a város nem más, mint egy név, egy jel, egy szimbólum, egy terminus, egy szlogen vagy ezek kombinációja, amelyek mind arra szolgálnak, hogy identifikálják a terméket, vagy a település által kinált szolgáltatások bizonyos csoportjait, így megkülönböztetik a várost a versenytársaktól, illetve a versenytársak által kínált szolgáltatásoktól. A marketingorientált településfejlesztésben a város neve a márka, 
hiszen a város neve egy tulajdonsághalmazt képvisel, amely elönyökkel és értékekkel szolgál a fogyasztóknak.

Azonosít minden olyan tényező, amely kapcsolatba hozható a termékkel, vagyis amely felkelti a figyelmet és hozzáad a termék értékéhez; a jellemzők, a szolgáltatások, a garanciák, a minőség, tehát minden, ami kielégíthet egy igényt. Fontos, hogy tisztába legyen a város vezetése azzal, hogy milyen attribútumok fontosak a célszegmensei számára; legyen itt szó az elérhetöségről, közvetlenségröl, hatalomról, avagy a kedvezményekröl (McCarthy 1960).

Ahogyan már említetésre került, a város mint termék több elemböl tevődik össze, mint például a politika, a szervezet, szimbólumok, struktúra, hagyomány, ideológia, rendezvények, kommunikáció, vezetés stb. A végső cél, hogy egy vonzó terméket alakitson ki az önkormányzat a célszegmensek számára.

A terméket úgy kell különféle jellemzőkkel ellátni, hogy ezáltal egy bizonyos helyet foglaljon el a fogyasztó agyában a többi város által kínált szolgáltatásokhoz viszonyitva. A célpiac számára - a többi város által képviselt értékekhez képest egy különleges, elhatárolt helyet kell elfoglalnia a településnek. A pozicionálás több módon is lehetséges; így a termék tulajdonságai szerint, a versenytársak elönyei-hátrányai szerint, illetve fogyasztói csoportok szerint. A pozícionálás sikerességét a hitelesség, a versenyképesség, a konzisztencia, illetve az üzenet tisztasága határozza meg (Jobber 1998).

\section{A termék fogyasztói}

A gazdasági szférában a vállalatok is azért fókuszálnak a vevőkre, mert csakis így lehetnek versenyképesek. Ezért az önkormányzatoknak is változtatniuk kellett a szemléletmódjukon, mert a város is nyer vele, hogyha a fogyasztóira figyel, hiszen ez az egyetlen módja a versenyben maradásnak és a fejlődésnek. Ezért egy olyan folyamatnak kell végbemennie a településfejlesztés folyamata során, ahol a város vezetése a fogyasztók igényeit, szükségleteit megfogalmazva alakítja ki fejlesztési tervét a sikeres város megteremtése és fenntartása érdekében. Tehát a középpontban nem az önkormányzatnak vagy a városnak kell állnia, hanem a fogyasztónak.

A városok esetében a fogyasztókat nem csupán a választópolgárok közössége jelenti, hanem a város területén müködô vállalatok és intézmények is. Ebböl is kitünik, hogy itt nem csupán kommunikációs tevékenységről, illetve a város imázsáról van szó, hanem egy tudatos, célpiaci igényeket követő vezetési szemléletröl. A célcsoportokat a lakosság, a vállalkozások, a különféle intézmények, illetve a turisták fö csoportjaira lehet elkülöníteni, melyek tovább bonthatók a jelenlegi, illetve a potenciális alcsoportokra (2. táblázat). 


\begin{tabular}{|c|c|c|}
\hline & $\begin{array}{c}\text { 2. TÁBLÁZAT } \\
\text { Fogyasztói csoportok } \\
\text { (Consumer Groups) }\end{array}$ & \\
\hline Fogyasztói csoportok & Jelenlegi & Potenciális \\
\hline Lakosok & $\begin{array}{l}\text { Jelenlegi állandó és } \\
\text { ideiglenes lakosok }\end{array}$ & $\begin{array}{l}\text { Potenciális állandó és } \\
\text { ideiglenes lakosok }\end{array}$ \\
\hline Helyi vállalkozók & $\begin{array}{l}\text { Jelenlegi vállalkozások, } \\
\text { termelószervezetek, szolgál- } \\
\text { tató szervezetek }\end{array}$ & $\begin{array}{l}\text { Potenciális vállalkozások, } \\
\text { termelöszervezetek, szolgál- } \\
\text { tató szervezetek }\end{array}$ \\
\hline Befektetök & $\begin{array}{l}\text { Jelenlegi hazai és külföldi } \\
\text { befektetők }\end{array}$ & $\begin{array}{l}\text { Potenciális hazai és külföldi } \\
\text { befektetők }\end{array}$ \\
\hline Turisták & $\begin{array}{c}\text { Jelenlegi belföldi, külföldi, } \\
\text { üzleti, szabadidős céllal } \\
\text { utazók, napi, hétvégi, tartós } \\
\text { üdülók }\end{array}$ & $\begin{array}{l}\text { Potenciális belföldi, külföldi, } \\
\text { üzleti, szabadidős céllal } \\
\text { utazók, napi, hétvégi, tartós } \\
\text { üdülök }\end{array}$ \\
\hline Szervezetek & $\begin{array}{l}\text { Jelenlegi hivatalok, pártok, } \\
\text { nemzeti és nemzetközi } \\
\text { szakmai és társadalmi } \\
\text { szervezetek }\end{array}$ & $\begin{array}{l}\text { Potenciális hivatalok, } \\
\text { pártok, nemzeti és nemzet- } \\
\text { közi szakmai és társadalmi } \\
\text { szervezetek }\end{array}$ \\
\hline
\end{tabular}

Forrás: Kraftné Somogyi 1998.

Összekapcsolva a marketingorientált településfejlesztésben a termék és a fogyasztó fogalmát, a marketing központi feladata, hogy értéket és elégedettséget szerezzen a fogyasztóknak, ezért az önkormányzatnak identifikálnia kell a fogyasztói szükségleteket, és ezekre a szükségletekre kell egy olyan terméket létrehoznia, amely értéktöbbletet teremt a fogyasztók kiválasztott szegmenseinek (Kotler et al 1999).

\section{Városok versenyképességének értelmezése}

A versenyképesség a városok esetében a városok közötti versenyben történő pozíciószerzést, illetve a versenyben való helytállást jelenti. A marketingorientált településfejlesztés esetében a versenyképesség értelmezésénél fontos a versenyképesség közgazdasági megközelítésétöl való elmozdulás egy új, területi megközelítés felé, hiszen a globalizációs, illetve regionalizációs folyamatok felerősödésével a versenyképesség új dimenziók mentén értelmezendö. A területi szint felerősödése folytán a verseny az egyes régiók és városok versenyévé vált, és ebben a 'küzdelemben' kell helyt állniuk a városoknak, a településeknek.

A területi egységek közötti verseny egy olyan folyamatként értelmezhetỏ, amely során „a regionális, helyi gazdaság fejlődését egyes csoportok a helyi politikákon keresztül - más térségekkel versengve - próbálják explicit vagy akár implicit módon" befolyásolni" (Lengyel-Rechnitzer 2000, 132). Ezek a csoportok a település jelenlegi vagy potenciális fogyasztói, akik saját érdekeiket képviselve vesznek részt a település fejlödésében. A területi verseny szereplöi az egyes területi egységek, így 
akár a városok egésze, amelyek eltéró érdekeit a versengő helyi csoportok jelenítik meg. A verseny célja a gazdasági fejlödés, amelyről csakis egy alulról szerveződő városfejlesztés esetén beszélhetünk. Bár a területi egységek közötti verseny föként gazdasági megfontolásokon alapul, mégis végeredményben az ott élők életszínvonalának a növelése a célja.

A területi verseny során a városok egyes funkciói, szolgáltatásai, adottságai, részpiacai és réspiacai versenyeznek, amelyben a keresleti oldalon a befektetések, a vállalkozások, a képzett munkaerő, az információ, az intézmények, a szervezetek állnak, míg a kínálati oldalon a város által nyújtott szolgáltatások, lakókörnyezet, biztonság, programok, befektetési környezet helyezkednek el (2. ábra). Mindezek együttesen hatnak a jövedelemszintre, az elégedettségre, a közösségtudatra és akár az identitásra is (Palkovits 2000). A verseny így különféle funkciókért, befektetésekért, fejlesztésekért, eseményekért, információkért, munkaerőkért folyik, melynek eredményeképpen növelhetö a településen az életszínvonal és a jólét is (Koltai 2004).

\section{2. ÁBRA}

$A$ városok versenyének értelmezése (Interpretation of Cities' Competitiveness)

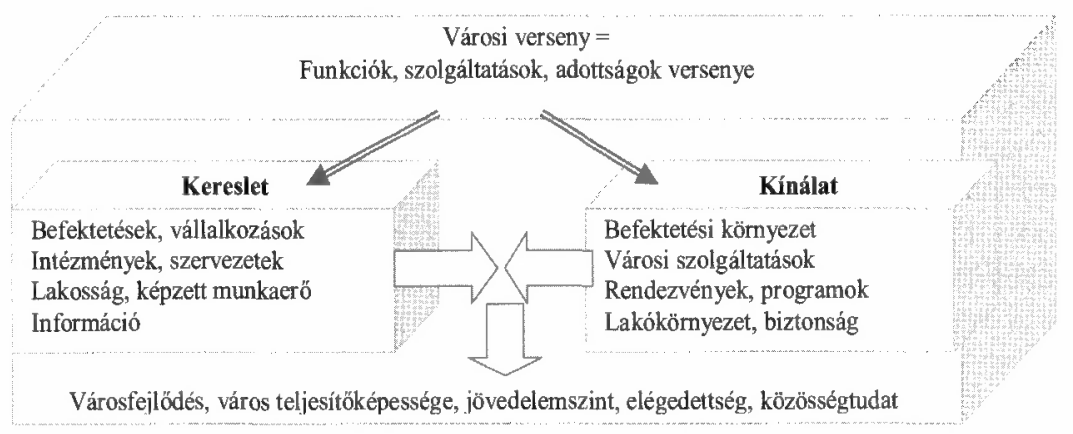

Forrás: Saját szerkesztés.

A területi versenyképesség sikere a gazdasági szerkezet rugalmasságában, a szolgáltató szektor előretörésében, az értékhúzó ágazatok magas arányában, a tudásalapú gazdaságban, az innovációban, a döntésközpontok jelenlétében, az erős középosztály meglétében, az értékes településkörnyezetben, az igényes várospolitikában, a színvonalas közszolgáltatások biztositásában, a negatív externáliák sikeres kezelésében, a más városokkal, régiókkal fennálló kapcsolatrendszerben, illetve a növekvő jövedelemben és foglalkoztatásban rejlik (Enyedi 1997).

\section{Marketingorientált városfejlesztés}

Kezdetben az önkormányzatok a marketing tevékenységet a népesség toborzása okán alkalmazták. Később az önkormányzati munka tudatosabb magatartást igényelt az intézmények részéröl a gazdasági szerkezetváltás, az urbanizációs trendek, 
az országok költségvetési problémái, a decentralizáció, a globalizáció, az információs társadalom felerỏsödése, a tercierizáció, a kvaternizáció és az idegenforgalom fellendülése következtében (Piskóti et al 2002).

Így a marketingorientált településfejlesztés kialakulásának okai között emlithető az önkormányzatok szemléletében bekövetkezett változás, miszerint több figyelmet szerettek volna fordítani városukra, hogy jobban megértsék a településen zajló folyamatokat. Továbbá, míg korábban a szolgáltatások és az infrastruktúra fejlesztése volt az önkormányzatok legfőbb feladata, mára sokkal aktivabb szerephez jutottak, melynek teljesítéséhez, a város sikeres irányításához vállalkozói megközzelités elsajátítására és alkalmazására van szükséges, amely - többek között - magában foglalja a privát és állami szektor közötti szoros együttmüködést, legyen szó lakásgazdảlkodásról, oktatásról, foglalkoztatásról vagy rekreációról.

A marketing ma a városok közötti verseny eszköze, és a városvezetés intézményi színterének a középpontja oly módon, hogy a helyes használata a fejlödés és a hatalom forrása (Mazzoleni 1998). Csak a tudatos és piacvezérelt önkormányzati fejlesztési tevékenység teremti meg annak a lehetöségét, hogy a város a kivánt ütemben és irányban változzon; tehát oly módon növekedjen, hogy ez a növekedés javítsa a település fogyasztóinak az életszínvonalát, továbbá, hogy a településen bövüljenek a gazdasági, társadalmi, kulturális lehetőségek, és ezáltal váljon vonzóbbá a különféle fogyasztói csoportok számára. A marketingorientációval tehát megteremthető a fejlesztési politikák preferált iránya, így olyan fejlesztések vihetők véghez, amelyek a fogyasztói igényekhez igazodva javítják az életszínvonalat, és a fenntarthatóságot szolgálják.

Gyakorlatilag a marketingorientált településfejlesztés magában foglal egy egész sor fogalmat és teóriát, melyeket profit és nonprofit szervezetek használnak arra, hogy eladják termékeiket, szolgáltatásaikat, ötleteiket a fogyasztóknak. A marketing, valamint a termékek és szolgáltatások piacára irányuló stratégiák egyre inkább áthatják, illetve befolyásolják az önkormányzati döntéshozatalt, a városok is egyre gyakrabban „marketingelik” saját magukat, hogy megteremtsék versenyképességüket. A marketingorientált városfejlesztés azonban több mint marketing, hiszen a marketingorientált városfejlesztés a magán- és közösségi érdekeket megszólaltató rendezési tervre épülö fejlesztés, információszolgáltatás, pénzügyi támogatás és koordináció.

A marketingorientalt városfejlesztés egy szemlélet, egy stratégia és egy eszközrendszer a város versenyképességének kialakitásához, megteremtéséhez, fenntartásához és kommunikálásához. Mindezekért a marketingorientált településfejlesztés nem csupán propaganda, reklám vagy kommunikáció, hanem egy komplex vezetési és szervezési szemlélet az önkormányzat részéről, amely piacorientált stratégiákból, illetve ezen stratégiákat megvalósító eszközrendszerekből tevődik össze. A marketingorientált településfejlesztés nem pusztán talpraesett szlogenekröl és propagandáról szól, hanem szervezetről, politikai, társadalmi és gazdasági szándékról és vezetésröl (Lees-Marshment 2001). 
A marketing egy eszközt kínál arra, hogy olyan városokat lássanak az emberek, amilyeneket szeretnének látni; ahol képes megújulni a városi környezet, $\mathrm{s}$ ahol a politika és a fejlesztések az emberek jólétének fenntartását és növelését szolgálják. Egy olyan várost szeretnének látni, ahol jó a kommunikáció és az infrastruktúra, ahol vannak kulturális kikapcsolódási lehetőségek, ahol megvalósíthatók az üzleti elgondolások (Smyth 1994). Ezért a marketing feladata, hogy megismertesse és eladja a település céljait, elképzeléseit, illetve, hogy a különféle szereplöket aktivizálja a város építésében való részvételre. Szükséges, hogy a résztvevők elfogadják az elképzeléseket, mert a város akkor válhat sikeressé, hogyha a fejlesztések a fogyasztói csoportok aktív támogatásával és magas szintủ közremúködésével valósulnak meg, ami csakis a marketingorientált településfejlesztésen keresztül teremthető meg.

Eszerint a marketingorientált településfejlesztés célja, hogy olyan fejlesztési stratégiákat alkosson az önkormányzat, amelyek promótálnak egy területet vagy egy egész várost bizonyos tevékenységre: fogyasztásra, termeló tevékenységre vagy ott lakásra. A hatékony marketingorientált településfejlesztés javítja a városról kialakult percepciót, s így növeli a bizalmat, a befektetöi és fogyasztói kedvet, következésképpen a marketingorientált településfejlesztésnek egy szintetizáló eszközként kell müködnie a település életében, amely végeredményként pozitivan járul hozzá a gazdasági, társadalmi, politikai folyamatokhoz.

Az önkormányzat szerepe abban rejlik, hogy ösztönöz, illetve visszatart egyes tevékenységeket, és így képes megteremteni, illetve élénkíteni a piacot. A városról alkotott vélemény azzal javitható, valamint a fogyasztók részvétele azzal növelhetö, hogyha a város fejlödése megegyezik a fogyasztói csoportok elképzeléseivel. Ezért a marketingorientált fejlesztés célja a különféle igények keresletté formálása, hiszen a kereslet megléte biztosítja a város versenyképességét, ami megteremti az emberek számára a gazdasági, társadalmi, környezeti jólétet.

A gazdasági érdekeken túlmenően az iskolák, a kulturális és tudományos intézmények, a lakosság mind-mind eltérỏ igényeket fogalmaznak meg a város vezetésével szemben. A marketingorientált településfejlesztés által a település a legnagyobb mértékben igazodik a kiválasztott célcsoport igényeihez úgy, hogy közben elösegíti a gazdasági és társadalmi folyamatok kedvező alakulását. A település adottságainak, értékeinek megismertetésén és a versenyelőnyök hangsúlyozásán túl az önkormányzatnak aktivizálnia kell a helyi társadalmat, meg kell szereznie a helyi társadalom támogatását a fejlesztési stratégia kidolgozásához és annak megvalósulásához (Petrétei et al 2001).

A marketingorientált városfejlesztési elméleti modell (MOVE) nem más, mint a marketing elvek és folyamatok alkalmazása az önkormányzati fejlesztési tevékenységek során; elemzés, fejlesztés, végrehajtás és kommunikáció annak érdekében, hogy vonzóvá tegye az önkormányzat a települést a kiválasztott célszegmensek számára (3. ábra). A marketingorientált településfejlesztés olyan komparatív versenyelőnyökre támaszkodó stratégiák kidolgozását, megvalósítását és kommunikálását foglalja magában, amelyek hozzájárulnak a település gazdasági, életmódbeli fejlődéséhez és fejlesztéshez. 


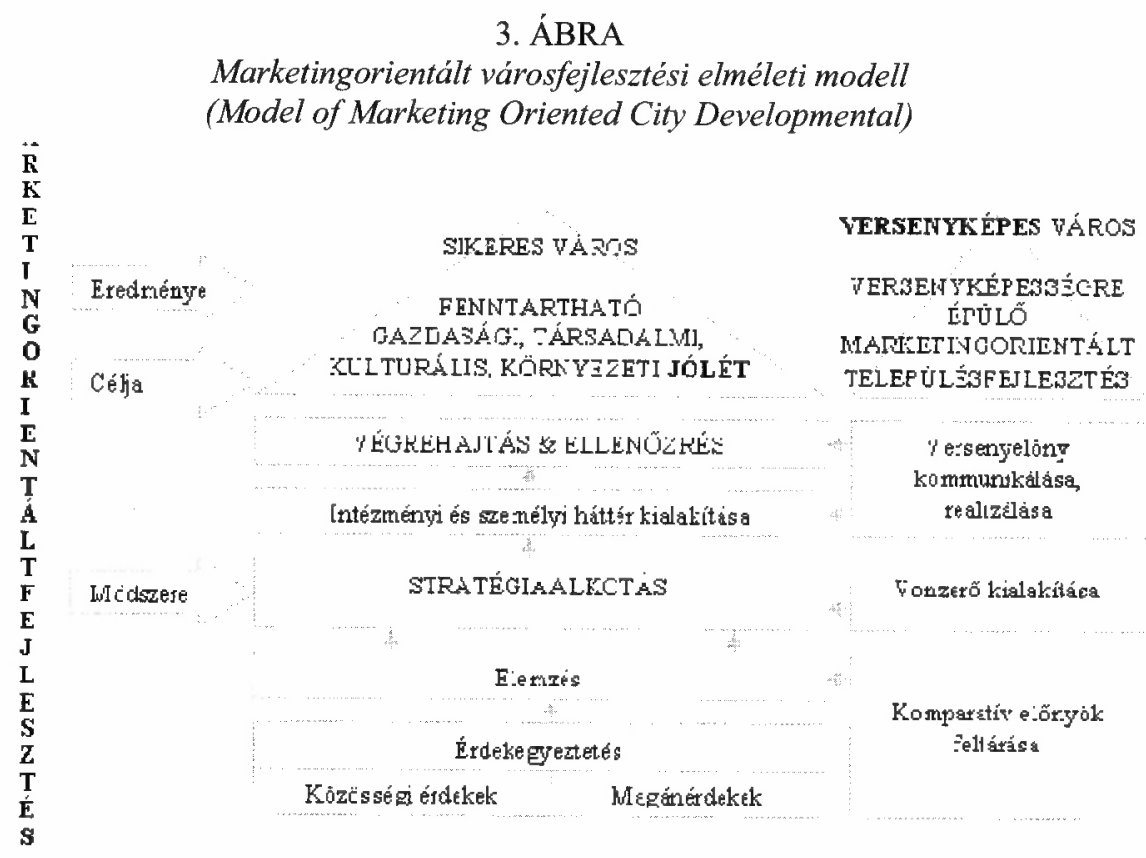

Forrás: Saját szerkesztés.

A településfejlesztés teljes folyamatát át kell hatnia a marketingszemléletnek, mert a településfejlesztési célok elérését szolgáló stratégiák és programok megvalósításában elengedhetetlen a marketingmódszerek és eszközök használata. A marketingszemléletủ településfejlesztés így olyan komparatív versenyelönyökre támaszkodó stratégiákat és módszereket takar, amelyek a lehető legnagyobb mértékben jelenitik meg a kiválasztott célcsoportok igényeit, s közben hozzájárulnak a település fenntartható fejlödéséhez gazdaságilag, politikailag, kulturálisan és társadalmilag. Így a marketingorientált városfejlesztés oly módon szolgálja a kitüzött gazdasági és társadalmi célokat, hogy közben mindezek a lehetó legnagyobb mértékben feleljenek meg a különféle célszegmensek elvárásainak, igényeinek, szükségleteinek.

A modellböl is látható, hogy a marketingorientált településfejlesztés nem csupán kommunikáció vagy $\mathrm{PR}$, hanem egy komplex vezetési szemlélet, stratégiaalkotás, illetve a stratégiát megvalósitó rendszer müködtetése, amely a település piacon történő megjelenítésére törekszik. A marketingorientált településfejlesztés tehát egy olyan szervezési tevékenységet igényel az önkormányzat részérỏl, amely megtervezi, koordinálja és érvényesíti a település csoportjainak az érdekeit, szükségleteit, majd meg is ismerteti mindezt ezen célcsoportokkal (Rechnitzer 1995).

A várostervezési és fejlesztési folyamatok sikerességének maximalizálása érdekében az önkormányzatok részéröl a magán- és közösségi érdekek összehangolására és megjelenitésére van szükség, hiszen egy település akkor válhat sikeressé, hogyha képes az eltérö érdekekböl közös fejlesztési célokat kialakitani, majd azokat képes 
megvalósitani. Ezért a marketingorientált településfejlesztés a település versenyképességének, komparatív elönyeinek feltárása, kialakítása, realizálása, majd kommunikálása.

A marketingorientált településfejlesztés szerint a város sikere a fogyasztók és az önkormányzati fejlesztések közötti közös értékekben rejlik, ezért a városnak artikulálnia kell a fejlesztési tervében, milyen értékeket képvisel. Ezen értékeket a tradicionálisan hozott értékeken kívül oly módon kell megfogalmaznia, hogy ezek válaszként szolgáljanak a célszegmens igényeire, szükségleteire, félelmeire.

Ekképpen az önkormányzatnak egy olyan szolgáltató rendszert kell alkotnia, amely követi a fogyasztók igényeit, azaz a területen élö, dolgozó vagy egyéb tevékenységet végző egyének és azok közösségeinek igényeit. A kínálati oldaltól a keresleti oldal irányába történö elmozdulảs eredményeképpen egy hatékonyabb és eredményesebb önkormányzati döntéshozatalnak és végrehajtásnak kell kialakulnia, amely képes alkalmazkodni és megfelelni a környezeti változásoknak, hiszen a városok közötti versenyt a politikai és gazdasági változások irányítják, így érdemi befolyással van rájuk mind a politikai decentralizáció, mind a gazdasági szerkezet átalakulása, vagy akár a globalizáció is.

\section{A marketingorientált településfejlesztés hatásai és lehetöségei}

A települések estében egyértelmüen beszélhetünk marketingorientált termékfejlesztésröl, hiszen a marketing velejárója minden olyan folyamatnak, amikor termékek, szolgáltatások, vagy értékek, ötletek cseréje megy végbe. Következésképp, marketing akkor történik, amikor egy csere folytán egy igényt kielégitünk; tehát mikor egy fogyasztó hozzájut egy kívánt termékhez vagy szolgáltatáshoz.

A marketingorientált településfejlesztés során az önkormányzat azon célból hajtja végre marketing tevékenységét, hogy meggyözze, illetve ösztönözze a fogyasztỏk megcélzott szegmenseit a város által kínált szolgáltatások igénybevételére. A marketingorientált településfejlesztés tehát nem más, mint az analízis, tervezés, implementáció, illetve program ellenörzés, amely arra hivatott, hogy kiépitse és fenntartsa a csereüzletet a célpiaccal a szervezeti célok elérése érdekében.

Érzékelhetö, hogy egy olyan folyamatnak kell végbemennie a marketingorientált településfejlesztés során, ahol a város vezetése a fogyasztók legfőbb igényeit, szükségleteit, érdekeit, aggodalmait, félelmeit megfogalmazva alakitja ki termékét a város iránti preferencia megteremtése és növelése érdekében. A piacon történő megjelenés segíti hozzá a települést ahhoz, hogy kialakítsa önön versenyképességét. A marketing segítségével látható, hogyan kerül „piacra” a város (4. ábra).

Az egész tervezés, fejlesztés és kommunikáció a fogyasztó igényei köré van szervezve, így az önkormányzat azt teszi, amivel képes eladni a települést a fogyasztók egyes csoportjainak. A marketingorientált településfejlesztés által a település tervei és fejlesztései biztosítják a helyi gazdaság fejlödését, a versenyképesség növekedését, a helyi gazdasági, társadalmi érdekek képviseletét, valamint a helyi politikai 
tevékenységek legitimációját. Mindez egy komplex vezetői szemlélet elsajátítását igényli a város vezetése részéről, hiszen itt egy szervezetről, egy intézményrendszerröl, de legföképp gazdasági, társadalmi szándékról van szó, amely a település fejlödését hivatott megteremteni.

\section{4. ÁBRA}

$A$ város piacon történö megjelenitésének tényezói

(Factors of Cities' Presentation on the Market)

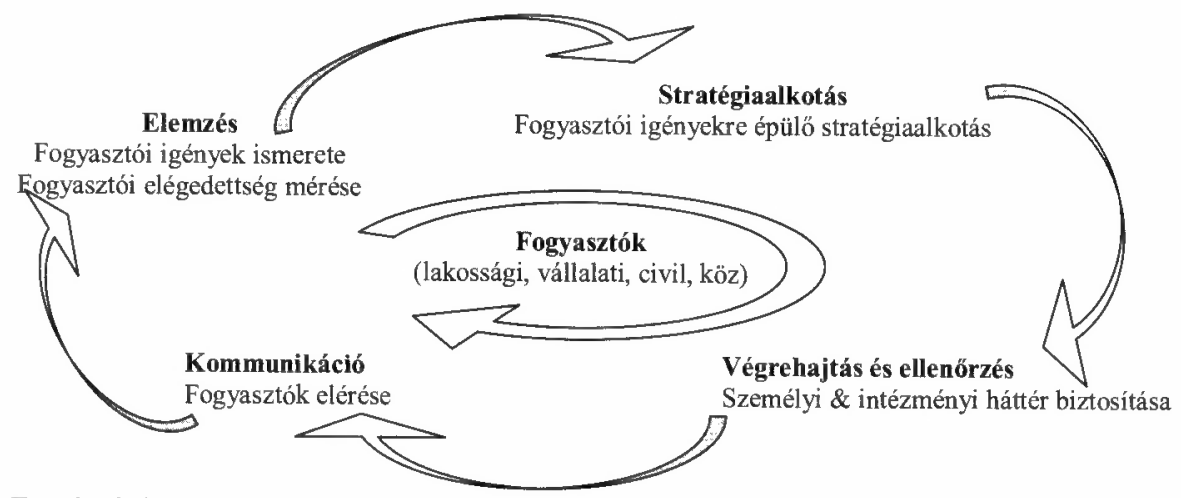

Forrás: Saját szerkesztés.

Megállapítható, hogy ma Magyarországon a marketingorientált településfejlesztési gyakorlat csak néhány esetben valósul meg, illetve jórészt a városok fejlesztési terveinek csupán egyes részeiben jelentkezik. A településfejlesztés során gyakori az egyes célcsoportokra történő fókuszálás, így például csak a turistákra vagy a befektetők vonzására irányuló stratégiák alkalmazása. A marketingorientált településfejlesztést ugyanakkor sokszor értelmezik kizárólag kommunikációs, reklámozási tevékenységként, illetve látható, hogy az egyes fejlesztési elemek, eszközök összehangoltsága hiányos, így például nincs egységes arculat sem, amely összefogná a település kommunikációját.

Mivel a marketing szemlélet során minden esetben a szolgáltatások bizonyos csoportjait kell eladni a célszegmenseknek, a marketingorientált városfejlesztés kapcsán a figyelem a városok bizonyos részeire irányul és nem a város egészére. $\mathrm{A}$ városról közvetített imázs nem tudja felölelni a teljes települést, ami esetlegesen növelheti a fejlödésbeli különbözöségeket, tehát a marketingorientált városfejlesztés által megtermelt haszon soha sem fog egyenletesen eloszlani.

Egy város tehát akkor képes megjelenni a piacon, ha a marketingorientált településfejlesztés modellben feltüntetett elemek egymással összhangban megvalósulnak. A megvalósulás pedig a kutatás eredményeinek a stratégiában való megjelenítésétöl, a végrehajtástól, az ellenőrzéstől és a kommunikációtól függ. Akkor mondható el, hogy a város jelen van a piacon, hogyha a stratégiában megfogalmazott üzenetek 
sikeresen eljutnak a fogyasztókhoz, és a fogyasztók ismerik és elismerik az önkormányzati fejlesztéseket és kezdeményezéseket, illetve részt is vesznek a város fejlódésében; mindezen elemek elengedhetetlenek a település versenyképességének megteremtéséhez.

\section{Irodalom}

Bányai, J. (1993) Önkormányzat és marketing. - Comitatus. November-december. 120-137. o.

Enyedi Gy. (1997) A sikeres város. - Tér és Társadalom. 4. 1-7. o.

Jobber, D. (1998) Európai Marketing. Müszaki Könyvkiadó, Budapest.

Koltai Z. (2004) Vállalati szempontok a magyar városok versenyképességének megitélésében. Fiatal Regionalisták IV. Országos Konferenciája. http://rs 1.szif.hu/ pmark/publikacio/Netware/tema.html

Kotler, P.-Armstrong, G.-Saunders, J.-Wong, V. (1999) Principles of marketing. 2. Prentice Hall Inc, New Jersey.

Kraftné Somogyi G. (1998) Településmarketing. - Fojtik J.-Rekettye G. (szerk.) Hagyomány és megújulás a magyar marketingoktatásban. Magyar marketingoktatók IV. éves konferenciảjảnak előadásai. JPTE KTK Marketing Tanszék, Pécs. 175-182. o.

Lees-Marshment, J. (2001) The Marriage of Politics and Marketing. - Political Studies. 4. 692-713. o.

Lengyel I.-Rechnitzer J. (2000) A városok versenyképességéről. - Horváth Gy.-Rechnitzer J. (szerk.) Magyarország terïleti szerkezete és folyamatai az ezredfordulón. MTA RKK, Pécs. 130-152 o.

Mazzoleni, G. (1998) La communicazione politica. Societá editrice il Mulino, Bologna.

McCarthy, E.J. (1960) Basic Marketing: Managerial Approach. III. Homewood, Irvin.

Palkovits I. (2000) Szempontok a területi versenyképesség értelmezéséhez - Tér és Társadalom. 2-3. 119-128. 0 .

Petrétei J.--Kiss L.-Iváncsics I. (2001) A településmarketing - Polgármesterek akadémiája: 2. modul. PTE Távoktatási Központ, Pécs.

Piskóti I.-Dankó L.-Schupler H. (2002) Régió-és település-marketing. KJK-Kerszöv, Budapest.

Rechnitzer J. (1995) Vázlatpontok a településmarketing értelmezéséhez és kidolgozásához. - Tér és Társadalom. 1-2. 5-16. o.

Smyth, H. (1994) Marketing the city: the role of flagship developments in urban regeneration. E\&FN Spon, London. 